\title{
Steve Kaplan, union official
}

Steve Kaplan worked for years as a visual effects artist on feature films, TV shows, and commercials. He then became an organizer for the Animation Guild [IATSE Local 839] in charge of the animation and visual effects sectors. He recruits new members, leads organizing drives, and educates existing members on the value of unionization. In this conversation, Kaplan discusses the distinctive challenges of organizing VFX workers.

You work for Local 839 now, but you started your career in visual effects.

Yes, I was part of a five-person team working on the production of The Sorcerer's Apprentice (2010). We were answering directly to John Nelson, the visual effects supervisor for the production, heading up a small in-house team.

Around that time I got my first iPhone. I started listening to podcasts. One of the first podcasts I subscribed to was called fxguide. I heard a guy named Jeff Heusser interview Steve Hulett, who talked about a union for visual effects artists. And I found that intriguing. Back when I was working for the Unified Film Organization we had talked about working under a union, but we all kind of scoffed and laughed at the idea since we were bulletproof twentysomethings who did what we did. No one gave it much thought. But when I heard that interview, and now being in my late thirties, I started to think more seriously about it.

Why didn't we all have health care? Why didn't we all have some kind of representation? And then Lee Stranahan's open letter to James Cameron came out just before Avatar (2009) was released. We all felt it would get the Oscar for 
visual effects. Lee wrote this long open letter saying, "Look, if you are going get the award for visual effects, and visual effects essentially is the reason everybody goes and sees film these days, why don't you give us a nod? If the effects artists are not going to get good conditions, if they are going to work themselves to death, if they are not going to have health care, how about you give them a pat on the back?"

But the conversation kind of died right there-most of my friends and certainly the four other people in the little FEMA trailer that we were in at Jerry Bruckheimer's editorial facility didn't want to talk about unionization. About that time the job was winding down, so I started to look for my next gig. I found this place that was looking for an organizer. I thought, I could at least apply and say I tried. I didn't think I was going to get it. There were about sixty people applying. They whittled it down to ten, and called me back for a second round of interviews. Two weeks later I got the call. The job was with the Animation Guild, but they wanted to hire someone to organize VFX workers.

\section{Tell us about your job.}

In broad strokes, my job is to organize animation and visual effects workers at facilities of all sizes. If work is being done in and around the Southern California area, which is our geographic boundary, we feel it should be union represented. So we identify places where work is being done without a union contract and then figure out if we have support from those working there in order to get a union contract. Typically that takes the form of identifying people at nonunion studios who have worked in union shops before. If you work in animation, chances are you carry an 839 card or did at some point in time because you inevitably pass through one of the studios that we have a contract with.

Starburns Industries, which is down the road, just signed a union contract. When Starburns started to do animation work in addition to their typical stop-motion work, we found out about it because somebody sent me an email saying, "I'm at Starburns now and I would love to have my union health and pension plan again. What would it take?" My first response is to get a crew list. Then you reach out to people. You gauge the level of interest. If there is a high level of interest, then the steps are pretty well defined by the Wagner Act of 1935. We distribute cards and gather signatures. If we get enough support through the cards we then knock on the door and say, "Hello, we are the union. The majority of your shop supports us. Do you want to talk with us?" If they tell us to go kick rocks, then we go to the government [National Labor Relations Board, NRLB], which then directs the company to recognize our showing of support and allow a representation election. If we win the election then we put a committee together and we sit and negotiate a contract. And if the negotiating committee and the 
employer are able to come up with a contract, then we go back to the unit and get the contract ratified.

\section{How long does that process take?}

Nick CG took five years. Now, it is important to note that Nick CG is a computer graphics unit inside Nickelodeon, which is in fact a union studio. So how long would it take to organize visual effects? I get this question all the time. My flippantsounding but actually quite accurate answer is that it will take as long as the visual effects artists want it to take. When Rhythm \& Hues was in its death throes we had a ton of people send us cards. We easily had well over the percentage we needed to feel comfortable going to the company and starting the process, but by that time Rhythm was in bankruptcy.

What were we going to do with that? There was no way we could make a contract with a company that was about to fold. So that hurt us in the sense that we had to then tell these people, "You came to us a little late." But at the same time, it's a pretty unique story. John Hughes's company was so artist-centric, and people felt such an emotional tie to it, that even when John said, "If you guys want a union, bring them in and I will talk to them," they said, "No, John. We love you. We are not going to do it." You have to realize that the attitude toward unionization in and around the United States is very, very cold. Just take a look at the numbers. The percentage of union membership in the United States in the 1970s was approximately 27 percent. Now it is approximately 8 percent. We are seeing a massive decline in what people understand a union to be, and that's part of the reason for the decline.

Do you think it's different in the animation business? Do those workers have more experience with a union and therefore more confidence in union representation? Does that make them different from visual effects artists?

I don't think there's much of a difference between the two. Overall, being a member of a union doesn't mean much to people today. I think it's because they don't understand the benefits. When you ask somebody what the benefit is of unionization they will show you their health card. But nobody understands the power of the collective voice. Nobody understands the intangible benefit of having those protections. It is unfortunate, but now in order to instill these you have to give a history lesson. And that makes you seem like a schoolmarm, rapping people on the knuckles, trying to tell them, "Hey, this is good for you." The biggest challenge to unionization in the animation world, and doubly so in the visual effects world, is that you have to answer, "Why union?" And you have to do it in a way in which you are not berating or coming across like a used-car salesman. 
You need to talk about the collective voice and the power to make change. But it is not like the union would have been able to stop Rhythm from dying. Rhythm died because John overextended himself in an industry that is asking people to overextend themselves. Rough Draft [another nonunion shop] survives because Claudia Katz [the firm's executive vice president] is a shrewd businessperson.

The artists at Rough Draft may not understand that being a part of a union means being able to keep these tangible benefits as you float around the industry, because plenty of people come and go from Rough Draft. What 839 wants to offer is a seamless cloak of benefits - that is, to make it possible for artists to move from studio to studio and maintain the same health and pension plans. Simply having a pension plan, an actual "defined benefit" pension plan-you don't see those anymore today.

The animation industry is in fact mostly union, or at least the places that most artists aspire to go: DreamWorks, Disney, Cartoon Network, Nickelodeon. But again, Rough Draft keeps a core staff of people and instills this culture of belonging within the studio and treats their people well. So because of that, you don't see a union at Rough Draft. Organizing small nonunion studios becomes difficult because people feel a sense of allegiance. Titmouse was very difficult to organize because Chris Prynoski is such a huge personality and he comes from Disney. He is a kid at heart, a big animated character himself. When you work for him you are like, "I love Chris Prynoski, he is so cool, and he makes these great films, so why would you want to attack Chris like that?" It's a disconnect. People think if they band together with their colleagues and form a union they're attacking their employer, and their city. People just don't understand the value of unionization.

You're making an argument for the union as a foundational package of benefits and protections. Yet in the visual effects business the workers you're trying to organize are deeply worried about the fortunes of the companies they work for.

It becomes very, very difficult to un-muddy the line. I think there is an extreme distinction between the visual effects artist working for major studios and the visual effects studios working for the producers. Scott Ross disagrees with me on this, but I don't feel that unionization means the death of the independent visual effects shop. Scott does, because Scott worked for Industrial Light \& Magic (ILM) and then Digital Domain. He saw how much the health and pension contributions cost. Therefore, he says, that burden would crush the shop. I counter that by saying, "How can music videos, commercials, and low-budget features survive with union contracts?" As a union, we need to be willing to adjust the contract to the conditions of the company we're working with. The goal and purpose of the union is to protect the member, but not at the expense of running their company into the ground. 
Back in the late 1960s all the union had to offer the employer was the Hollywood basic agreement. You simply signed that. But then the entertainment paradigm started to change. The basic contract was written in the 1940s and 1950s. Things changed and unions needed to adjust the agreement. Overall, it is better to be doing covered work than non-covered work. So let's figure out a way to make it work.

We have three tiers of budget that are considered before somebody signs the basic. And if those tiers aren't met, then you have production agreements. We have agreements for feature films, movies of the week, music videos, and commercials. All of these agreements now take different budget concerns into consideration and they make adjustments for what the workers want. Is there a pension contribution at all? Are you a part of our Cadillac health plan or are you part of this other health plan that still offers health coverage but at a lower cost and therefore might be a better fit for particular shops?

I think that model can easily translate into visual effects. If you take a look at how the IATSE National Benefits Funds are structured, it already is geared toward visual effects. It is geared for the "day player." It is geared for people who work outside the coasts and in the middle of the country where maybe costs are down but benefits are still needed. We can easily bring that into the visual effects world and make it work. So I reject Scott's notion that an \$8 per hour, per employee contribution is going kill the visual effects shop. Sony Imageworks can afford the Motion Picture Industry Pension and Health plan. Could Joe VFX, down the street? No. Joe VFX is battling with Imageworks, or is trying to get episodic work, or is competing against subsidies in Canada. It may have a core team of six to ten people who render through an Amazon service so Joe doesn't have to buy his own render farm. He is making it work and we want him to succeed. That is where the flexibility of today's union comes in, and yet very few people are aware of that aspect.

\section{Who are the key players in the VFX business right now?}

Scott Ross says eight shops in the world are capable of doing what he calls A-level work: Imageworks, ILM, Motion Picture Company (MPC), Weta, Framestore, and a few others. For 839 to organize them is almost impossible at this point because none of them are here in Southern California. If you are a big player, you are in Vancouver or somewhere that's offering attractive subsidies.

So who is left in L.A.? Digital Domain went through bankruptcy. Rhythm \& Hues went through bankruptcy.

But they're still around. They went through bankruptcy and then were sold. Rhythm \& Hues is now owned by the holding company that owns Prana Studios. 
They have approximately eighty people [down from more than five hundred] in the El Segundo office who are still bidding for work.

Digital Domain is alive. They have approximately three hundred to four hundred people in Vancouver who do feature work. Ed Ulbrich made the announcement that Digital Domain was never going to do feature work in Los Angeles again and they were going to vacate that facility come hell or high water. That decision was made because of subsidies. Originally their plan was to expand their Playa del Rey facility where commercials are done, and add feature work. But instead they moved most of that work to Vancouver, where it's subsidized. They did keep some feature workers here; I want to say 150 or 160 people have been shoehorned into the Playa del Rey facility. So Digital Domain is still around, it is still in Los Angeles, but it mostly does commercials here.

There are a range of smaller shops, like Zoic, that remain in L.A. but aren't doing feature work here. Most of their revenue in L.A. comes from commercials, maybe some episodic television, but even that has moved to their offices in Vancouver.

Lower-tiered mom-and-pop shops are opening up all the time in L.A. I think that what is left in Southern California are either houses with roots too deep or wills too strong to move. And what they are doing is finding a way to make it work. VFX is not just for feature films or TV. It's in Internet, mobile, and magazine art. In addition to media clients, it has industrial, military, medical, and education clients. Visual effects and visualization are being done in a lot of industries. I mean, we are not seeing the end of it here in Los Angeles. Plus, the technology itself is growing with $3 \mathrm{D}$ and virtual reality. The opportunities are still out there.

\section{Can you tell us more about the mom-and-pop shops?}

Sure. As I was pointing out, I know plenty of people who worked at Rhythm \& Hues, Digital Domain, or Imageworks who are starting their own shops. They say, "We have enough contacts. We have enough money. We have enough skill to land small contracts or pieces of big ones." These people are working out of garages and back rooms like they did twenty years ago. They have gone back to that model and have tried to streamline it, and in addition to traditional content formats, all of a sudden now they are doing other things like web and mobile content. They diversify in medical and military.

\section{Is anyone doing feature work in L.A.?}

No. Well, I want to say no. But it's also true that Imageworks had three or four hundred people working on The Smurfs 2 (2013) and Cloudy with a Chance of Meatballs 2 (2013) here because they couldn't fit more people into Vancouver. Now it is becoming very difficult to send work to Vancouver. Vancouver is becoming 
very protective of its subsidies because over the course of three years it spent more than a billion dollars and they're not getting the returns they imagined. They now realize that the same tax coffers that pay for a provincial health system are being tapped for the Hollywood Big Six. And it is strictly in bags of cash, by which I mean it is simply a cash handout. These are not tax breaks. It is just, "You can have the money if you do the work here, but you must do the work here." That is what is written into a lot of production agreements.

We've been talking a lot about contracts, companies, unions, and benefits. What about the VFX artists who are still here in Los Angeles and working for, let's say, a medical device company?

A buddy of mine works as a supervisor in one of these alternative companies and longs for the day when he can go back to television or feature work. Yet he enjoys more security in his new position. In previous incarnations of his work he worked for big companies but not inside of a big company. He didn't work for an Imageworks or a Digital Domain. He worked for a smaller firm that subcontracted with Imageworks or Digital Domain. So because he worked for these smaller firms doing feature work, he essentially took it in the shorts. Smaller firms are more likely to be the ones that cut costs and pass that cut down to the artists in order to get the big feature work. They're looking for prestige, or at least looking to get their foot in the door. Creatively, my buddy would rather be doing feature work, but he's better off where he is now. If you are absolutely stuck on feature work or stuck on episodic work, then go buy a plane ticket.

And people are picking up and relocating.

Yes. A lot. Vancouver, London, Wellington. Five of my personal friends are working on projects in London right now.

Did the closing of Digital Domain and Rhythm \& Hues mark the end of an era in Los Angeles?

Yes. You had Imageworks, Rhythm, and DD, which were the big houses working on features. If you go further back in time you had some of the smaller houses working on features. There are still plenty of artists in town working on games. Games are still here. But that's leaving for the subsidies as well.

What's your take on the subsidies issue?

You can't tell Vancouver what to do. You can't just say stop with the subsidies over there. Officials were elected lawfully by their constituencies and they de- 
cided to offer subsidies. Nothing the United States can do would change that, short of a trade war with sanctions and posturing. So our only recourse as VFX artists in Los Angeles is to go through the World Trade Organization because there is language in the WTO trade agreements that talks about the harm of subsidies. The challenge, however, is that the US trade representative has to pick up that charge. And that person has all sorts of political ties and commitments. It's difficult to use a politician to further your cause, so we're taking the legal route.

Countervailing duties have been used to change practices in lumber, shrimping, and other industries, but in those cases you were physically able to go to a dock and say this lumber came from Canada, or this shrimp came from Japan, or something else that you could physically touch. We need to understand digital files of visual effects in the same way. Digital files are just as valuable as that shrimp or that lumber. So the argument has to be made in a courtroom that this was the industry in the United States before subsidies and this is the industry after, and this is the effect it has had on workers. This local homegrown industry has been injured and subsidies are the reason.

\section{What is it like to work in a VFX shop in Los Angeles these days?}

Much of the work is doing commercials, which are six- to eight-week gigs. You are likely going to be misclassified as an independent contractor, which means the company will pay you a flat rate and most likely without any overtime, but you will work overtime: long, long hours. Eighteen hours per day is a norm. Independent contractors don't get benefits or unemployment insurance. If you report $\$ 120,000$ a year as an independent contractor you have to have a business license and you have to worry about taxes, accounting, health care, and retirement. Most likely it's best for you to incorporate. And then you have to spend a good amount of time finding yourself some tax shelters. You learn to play "funny-money" games. All of this takes time and energy.

Conditions at these studios aren't terrible as far as actually sitting there and doing the work if you don't mind the long hours. These studios tend to be retro and cool. A lot of them buy food for employees or provide the means for storing and preparing food. They have refrigerators and microwaves. They will do a barbecue once a week, some things like that. They have ping-pong tables. If you are an artist you know the name of everyone at these houses and hopefully you are on good terms with every one of these houses. You have to be. It's long hours and tight quarters. It is not conducive to what I would consider a family lifestyle. I'm forty-two years old and all of my friends in the industry are around that age, and plenty of them have families and work in this environment. It is stressful, but so is my job. 
How old are the employees in these small shops?

I would say they're dominated by people from their mid-twenties to early thirties. Most people in my age group are either managers or they work for a regular studio, or they've moved on to something else.

If someone is thirty-five and wants to get out of the game, where do they go?

I was speaking to a friend of mine this weekend who is writing a business plan for a paleo food truck. Another colleague has a Kickstarter campaign going for 3D-printable chocolate. He is going to try to start a business that prints novelty chocolates that are company logos. So it's all over the place.

What about the gender dynamics in these shops?

I think we are seeing more women in animation than ever before. But it is still a heavily male-dominated profession. Unfortunately, visual effects is like animation. There are far more men working in the industry than women.

We've read that wages have dropped anywhere between 20 and 40 percent.

Absolutely. I know people who used to make $\$ 75$ an hour and now are making $\$ 55$. I also know people who used to make $\$ 75$, but are now making $\$ 35$ or $\$ 40$ - that's a really tough drop. There are people who still earn a good living at, say, $\$ 65$ an hour. If you're employed throughout the year, you're pulling down six figures, which is very, very nice. But most people are seeing their incomes decline. I have one friend, for example, who has done vast amounts of feature work. He is now working episodics in L.A. His feature rate was around $\$ 70$ per hour. He is making $\$ 50$ now. He is extremely good at what he does. He is in demand. But he still spends maybe three to four months a year unemployed.

\section{Is that common?}

Yep. Unless you work for DreamWorks or Disney. Disney hires and doesn't let go. Well, that is not entirely true. Disney lets some people go. Near the end of a film, Disney will put out a 911 call, the, "Oh, my god, we've made too many changes and the drop day is coming! We need tons of people!" So they will hire folks for a sixto-eight-month stretch and then let them go.

But if you are working in a union environment, like Disney, you can get longterm gigs. DreamWorks will keep people on. In fact, DreamWorks is now starting a television division. It's indicative of the changing entertainment paradigm. Amazon 
wants to take on Netflix. So Amazon approaches Viacom and says, "We need content. Would you sign an exclusivity deal? Hey, we love kids' material." So what does Netflix do in return? Their people go to Jeffrey Katzenberg at DreamWorks and say, "We need content." Jeffrey says, "Pay me." To which Netflix replies, "Sure, we will give you $\mathrm{X}$ amount over three years as long as you can deliver thousands of hours of content."

So what is DreamWorks doing? They rent two floors in a building on Central Avenue and they are starting DreamWorks Television. They are hiring folks who do television animation and they are going to put two hundred to three hundred people to work doing these thousands of hours of content. If you can get a gig like that you can plan for a year. You can plan for two. But for most people, it's not like that, so it's hard to be married and have kids and feel comfortable.

\section{Are the animation and VFX shops at the major studios unionized?}

Not necessarily. Disney owns Pixar. So we often hear, "Disney is union; does that mean Pixar is as well?" The answer is no. Our contracts are very specific in regards to scope. People also ask what will happen to ILM now that Disney bought LucasArts.

Disney owns visual effects studios, but they hate them. They don't fit their model. Why? Because Disney is very money-oriented. They will spend $\$ 4$ billion on LucasArts or $\$ 7$ billion on Pixar because they will make money on that deal, but not on visual effects. When you buy Pixar, you own Pixar. If you spend $\$ 7$ billion on it you will make that back in two years because Pixar movies make money. Disney bought LucasArts because owning LucasArts means you own Star Wars. Acquiring ILM as part of that deal is another story. Visual effects companies simply don't make money. There is a lot of money that flows through them, but the companies themselves don't make money.

Do you think it would make sense at some point for the effects companies to form a trade association?

They absolutely should. If I'm going to advocate organization for the artists, the next step is to advocate for an organization for the VFX studios. Both groups need to do this so that we can go to the producers and say, "You need us." Organized artists couldn't go to the producers alone to demand change. Organized shops couldn't do it, either. Producers would simply exploit the situation by playing one group against the other. They would go to the artists and say, "Start your own companies." Or they would go to the companies and say, "Hire more nonunion artists." The producers will shuffle the cards.

But if you can combine those fronts, you can go to the producers and say, "You are going to sit with both groups and bargain. If you are going to do work with us 
you are going to guarantee certain things. Here is what change orders cost. Here is a proposal for realistic scheduling. You are going to agree to all of these terms if you want to work with us."

But you have to be able to do that on a global basis.

Sure, eventually. That's not to say it has to start globally or be enacted globally at the same time. That would be practically impossible, but eventually that's where you want to go. The axiom "A rising tide lifts all boats" would best describe my point of view. You are not going to get them all at once. Just like you are not going to get every visual effects house in Los Angeles to go union at once.

\section{Is there a culture of fear in the VFX community right now?}

Absolutely, but it's not just fear. You might say, "fear-greed." Getting owners and managers of the shops to sit down and talk to each other is difficult. Scott Ross did it. He brought the shops together around a table to discuss a trade association. Everyone at the table had a lawyer behind them, I kid you not. They spent two hours talking, but it was very difficult. Scott literally pulled the rest of his hair out. He was like, "What are you doing? I'm one of you. I have seen this. I ran ILM. I ran DD. I saw the independents. We need to do this together!" And they are all like, "You know what, we have six people [the major Hollywood studios] who pay us. There are six people who use our services. If two of them are mad at us, the rest of them get mad because they are all buddies."

So the ultimate irony in all of this is that the only people who are organized and use collective leverage are, in fact, the feature film producers working for the big Hollywood studios.

\section{And the worst part is that the globalization of VFX work enhances their leverage.}

Exactly, but I still believe this industry will eventually organize. The producers are so money driven that they don't care about the plight of the visual effects shop or the workers. They know they can just get it from somewhere else, either another shop locally that's hungry for work or from somewhere else on the other side of the world. They just follow the money. They didn't even engineer the subsidy game; Canada did. But producers have leveraged it. So now they've got people paying them to do work on their movies. At some point in time that is going to fail. You are going to see it in British Columbia first, an environment that has become a bubble economy, where you wonder if in the end it all adds up. Eventually something is going to fail. What happens then? I don't really know. 